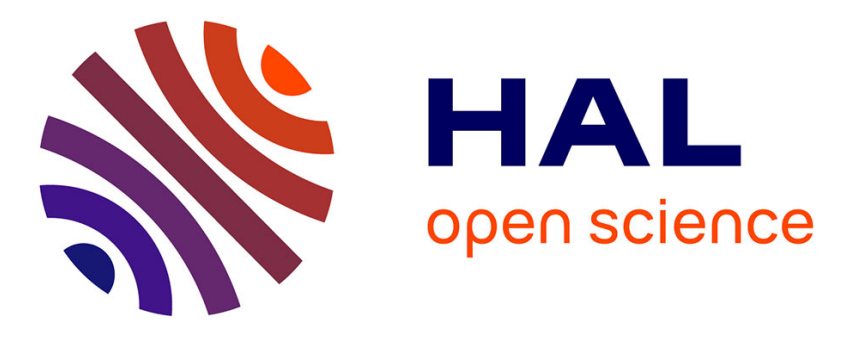

\title{
First detailed description of Hispanomys decedens (Rodentia) from the Middle Miocene of La Grive-Saint Alban (France)
}

Raquel López-Antoñanzas, Pierre Mein

\section{- To cite this version:}

Raquel López-Antoñanzas, Pierre Mein. First detailed description of Hispanomys decedens (Rodentia) from the Middle Miocene of La Grive-Saint Alban (France). Swiss Journal of Geosciences, 2011, 104 (2), pp.345 - 353. 10.1007/s00015-011-0066-0 . hal-01920848

\section{HAL Id: hal-01920848 \\ https://hal.science/hal-01920848}

Submitted on 17 Dec 2020

HAL is a multi-disciplinary open access archive for the deposit and dissemination of scientific research documents, whether they are published or not. The documents may come from teaching and research institutions in France or abroad, or from public or private research centers.
L'archive ouverte pluridisciplinaire HAL, est destinée au dépôt et à la diffusion de documents scientifiques de niveau recherche, publiés ou non, émanant des établissements d'enseignement et de recherche français ou étrangers, des laboratoires publics ou privés. 
First detailed description of Hispanomys decedens (Schaub,

\section{2}

1925) (Rodentia) from the Middle Miocene of La Grive-Saint

\author{
Alban (France)
}

\section{Saint Alban (France)}

Running Title First description of Hispanomys decedens

$$
\text { Raquel López-Antoñanzas }{ }^{1} \text { and Pierre Mein }{ }^{2}
$$

${ }^{1}$ Departamento de Paleobiología, Museo Nacional de Ciencias Naturales-CSIC, c/ José Gutiérrez Abascal 2, Madrid 28006,Spain.E-mail: ralopan@mncn.csic.es

${ }^{2}$ Département des Sciences de la Terre; Université Claude Bernard - Lyon I; 27-43 Bd. du 11 novembre 1918; Villeurbanne 69622 cedex, France.E-mail: Pierre.Mein@univ-

$$
\text { lyon1.fr }
$$

\footnotetext{
Abstract The material of Hispanomys decedens (Rodentia, Cricetodontinae) from La Grive-Saint Alban (France) is described in detail for the first time. Hispanomys decedens, which is one of the oldest species of the genus, shows the primitive character states that are typical of the Aragonian congeneric species, such as the mesolophs and
} 
22 labial cingula surrounding the upper molar valleys. The detailed examination of the

23 teeth of $H$. decedens shows that this taxon is a good candidate ancestor for $H$.

24 aragonensis.

26 Résumé Le matériel d'Hispanomys decedens (Rodentia, Cricetodontinae) de La

27 Grive-Saint Alban (France) est décrit pour la première fois en détail. Hispanomys decedens est une des plus anciennes espèces du genre et montre des caractères primitifs typiques des espèces congénériques aragoniennes, tels que la présence de mésolophes et

30 de cingulums labiaux sur les molaires supérieures. L'étude détaillée d'Hispanomys

31 decedens montre que ce taxon est un bon candidat au titre d'ancêtre d'H. aragonensis.

33 Keywords Hispanomys $\cdot$ Cricetodontinae $\cdot$ La Grive-Saint Alban $\cdot$ France $\cdot$ Systematics

34 Mots clés Hispanomys $\cdot$ Cricetodontinae $\cdot$ La Grive-Saint Alban · France $\cdot$ Systématique

\section{Introduction}

La Grive-Saint-Alban is the name used to refer to various Upper Aragonian pits located

40 on the territory of the municipality of Saint-Alban-de-Roche (Isère, France). These pits

41 are constituted by fissures in limestones filled with fossiliferous siderolitic clays.

42 Remains of Hispanomys have only been recovered from La Grive L (quarry Lechartier),

43 M (quarry Milliat), and P.B. (quarry Peyre et Beau, where a single $\mathrm{m} 1$ was found by P.

44 M.). La Grive L has eight fissure-fillings numbered from L1 to L8, but the only 
productive ones (from a palaeontological viewpoint) are L3, L5, L5', L6, and L7 (Mein and Ginsburg 2002).

In 1887, Depéret revealed the presence of two taxa of Cricetodon at La Grive SaintAlban: C. medium and C. rhodanicum (Depéret 1887a, 1887b). In 1925, Schaub carried out a whole revision of the cricetine myomorph rodents. He included in the species $C$. sansaniensis Lartet, 1851 all the large-sized species of Cricetodon from Upper Aragonian localities: Sansan (Gers, France), La Grive Saint-Alban, various sites from the Swiss molasse, and the Steinberg (=Spitzberg) in the Nördlinger Ries, southern Germany. In this work, he synonimized $C$. rhodanicum with $C$. sansaniensis because these taxa could not be differencied neither by the morphology nor by the size (Schaub 1925: 9). In addition, in the course of his revision of the material of $C$. sansaniensis housed in the Museum of Lyon, he noticed the presence of two morphotypes within the material of $C$. sansaniensis from La Grive Saint-Alban: the first, slightly larger and with less developed ectolophs corresponded to C. sansaniensis, whereas the smaller one, with better developed ectolophs, revealed a different variety (Schaub 1925: 13), which he named Cricetodon sansaniensis var. decedens.

$$
\text { Later on, this variety was raised to the species level (Schaub 1944: 454; Schaub }
$$
1947: 60). Mein and Freudenthal (1971: 19) introduced the subgenus Hispanomys for a handful of allegedly derived Cricetodon, such as C. decedens. This subgenus was elevated to the genus level by van de Weerd (1976: 106 et seq.). The holotype of $H$. decedens, which is a left maxillary fragment with M1 and M2, is housed in the MSNL (Schaub 1925). It seems that the original findings of H. decedens are not the fruits of the field works carried out by Depéret in the mid-XIXth century, but most likely of those carried out shortly later by Gaillard, which were taken up by Ennouchi in the beginning 
of the XXth century. It is believed that Ennouchi worked in the "Carrière Lechartier"

70 (called at that time "Carrière Chemin") at the fissures L4, L5, L5', and L7 (Ennouchi 1930). The remains of $H$. decedens are supposedly from a now empty fissure, which is located between the fissure L5 and L7 and that is called L5'.

Although $H$. decedens from La Grive-Saint Alban has been mainly found in the fissure-filling L5', it has also been recorded in fissures L5, L7, as well as in La Grive M (Mein and Ginsburg 2002). Additional material of this species has been mentioned by Alba et al. (2006) and Casanovas-Vilar (2007) from various MN7/8 sites of the Can Mata series (Barcelona, Spain).

The other species of Hispanomys found in La Grive-Saint Alban is H. bijugatus, which has been recorded from fissures L3 and L5 and has been described in detail in López-Antoñanzas and Mein (2009).

Hispanomys decedens is to date the less-known species of Hispanomys. Actually, no complete description or photographs of this important material have been made available so far. Therefore, the aim of the present work is to offer a detailed description of this taxon, which has been neglected until now.

\section{Material and methods}

The systematic study presented below is based on the examination of original

89 specimens of the MNCN, RUU, IPS, and FSL collections (see below for abbreviations),

90 and data from the literature. We examined the following: original teeth of Hispanomys

91 bijugatus and $H$. decedens from La Grive Saint-Alban (Isère, France), H. mediterraneus

92 from the localities of Montredon (Hérault, France), Soblay (Ain, France), and Dionay 
93 (Isère), H. aguirrei from Escobosa (Soria, Spain), H. daamsi from Can Missert

94 (Barcelona, Spain), H. dispectus from Hostalets de Pierola and Castell de Barbera

95 (Barcelona), H. lavocati from Hostalets de Pierola, H. aragonensis from Pedregueras

96 2A (Saragossa, Spain), H. nombrevillae from Molina de Aragón (Guadalajara, Spain),

97 H. peralensis from Peralejos 4, Peralejos C, Peralejos D, Masía del Barbo 2A, and

98 Masía del Barbo 2B (Teruel, Spain), H. moralesi from Batallones 1, Batallones 3,

99 Batallones 5, and Batallones 10 (Madrid, Spain), H. thaleri from Can Llobateres

100 (Barcelona), H. freudenthali from Puente Minero (Teruel), and H. adroveri from Casa

101 del Acero (Murcia, Spain).

102 Measurements of the occlusal surface of the teeth (maximum length and maximum

103 width) have been taken following the method of van de Weerd (1976) for all dental

104 elements except for the second upper molars, for which the maximum length has been

105 taken parallel to the labial side of the tooth. Measurements were obtained with a Nikon

106 digital counter CM-6S measuring device (Table 1).

107 First, second and third lower molars are designed as m1, m2, and m3, respectively,

108 whereas first, second and third upper molars as M1, M2, and M3. The terminology used

109 in the tooth descriptions follows that of Freudenthal et al. (1994) and López-Antoñanzas

110 et al. (2010).

111 Since de Bruijn et al. (1992), the biozones MN7 and MN8 have been grouped into a

112 single unit MN7/8 due to the impossibility to distinguish them. However, Mein and

113 Ginsburg (2002), based on the different species of Democricetodon recorded in the

114 different fissure-fillings of La Grive-Saint Alban, were able to differenciate them in this

115 area. They considered La Grive M and La Grive L3 as reference sites for the biozones

116 MN7 and MN8 respectively, a conclusion with which López-Antoñanzas and Mein 
117 (2009) agreed. Thus, in this work, we apply the biozonation given by Mein and

118 Ginsburg (2002) for the fissure fillings of La Grive-Saint Alban.

119

120 Institutional Abbreviations

121 FSL Université Claude Bernard, Villeurbanne, France

122 IPS, Instituto Catalán de Paleontología, Sabadell, Spain

123 MNCN Museo Nacional de Ciencias Naturales-CSIC, Madrid, Spain

124 MSNL Centre de Conservation et d'Etude des Collections, Lyon, France

125 RUU Rijksuniversiteit Utrecht, Utrecht, The Netherlands

126

1273 Systematic paleontology

128

129 Order Rodentia BowDICH, 1821

130 Subfamily Cricetodontinae ScHAUB, 1925

131 Genus Hispanomys MeIn et Freudenthal, 1971

132 Species Hispanomys decedens (ScHAUB, 1925)

$133 \quad$ (Figs. 1, 2, 3)

134

135 Holotype - ML-Lgr 130: left maxillary fragment with M1 and M2 (Schaub 1925:

136 fig. 2, plate III)

137 Referred specimens - FSL67000, FSL67001, FSL67002, FSL67003, FSL67005,

138 FSL67006, FSL67100, FSL67103, FSL67105, FSL67106, FSL67107, FSL67118,

139 FSL67121, FSL67122, FSL67142 (mandibular ramus with m1-m3); FSL67004,

140 FSL67021, FSL67101, FSL67120 (mandibular ramus with m1-m2); FSL67098 
141 (mandibular ramus with m2-m3); FSL67093-FSL67097, FSL67104 (isolated m1);

142 FSL67047-FSL67052, FSL67060-FSL67065 (isolated m2); FSL67053-FSL67059,

143 FSL67111 (isolated m3); FSL67007, FSL67009-FSL67011, FSL67046, FSL67110

144 (maxilla with M1-M3); FSL67008, FSL67109, FSL67112-FSL67117, FSL67119,

145 FSL67123, FSL67124, FSL67126, FSL67129, FSL67134-FSL67140, FSL67143-

146 FSL67147 (maxilla with M1-M2); FSL67125, FSL67128, FSL67130, FSL67141

147 (maxilla with M1); FSL67127 (maxilla with M2); FSL67012-FSL67017, FSL67022-

148 FSL67045 (isolated M1); FSL67018-FSL67020, FSL67066-FSL67084 (isolated M2);

149 FSL67085-FSL67092 (isolated M3). Measurements are given in Table 1 and Fig. 4

150 Type locality - La Grive-Saint Alban (fissure L5')

$151 \quad$ Age - Probably MN 7

152 Other localities - La Grive-Saint Alban (Carrière Milliat « M », Carrière Lechartier,

153 fissures L5 and L7*), Isère, France (Mein and Ginsburg 2002); Hostalets de Pierola,

154 Barcelona, Spain (Alba et al. 2006; Casanovas-Vilar 2007).

$155 *$ All the three localities are very poor in remains of $H$. decedens. The extremely low

156 proportion of this taxon in the fissure L7 has been considered to be possibly the result of

157 “contamination” by Mein and Ginsburg (2002).

158 Extended diagnosis - Hispanomys species of medium size with low hypsodonty;

159 having low values of the mean LM1/mean LM3 (=1.74) and mean Lm1/mean Lm3

160 (=1.16) ratios (third lower and upper molars not reduced); lower molars usually lacking

161 the cingula on the lingual valleys; with some $\mathrm{m} 1$ having a double metalophulid or a

162 short mesolophid or even both; three rooted $\mathrm{m} 2$ with a short, but distinct, mesolophid;

$163 \mathrm{~m} 3$ having a long or short, but distinct, mesolophid; M1 and M2 having labial cingula

164 surrounding their valleys and usually having a mesoloph and an enamel-coated valley; 
165 four-rooted M1 having one or two anterior cusps on the prelobe, with the anterior

166 ectoloph well developed, but lacking the fordward paracone spur and usually having

167 prominent protostyles and entostyles; M2 with lingual anteroloph, having the

168 anterosinus usually open, but having sometimes anterior ectoloph and fordward

169 paracone spur, less M2 than M1 with mesoloph and enamel-coated valley, and all of

170 them having well-developed backward paracone spur and posterior ectoloph; M3 with

171 distinct anteroloph and posteroloph and having backward paracone spur, but lacking the

172 anterior ectoloph, the fordward paracone spur, and the posterior ectoloph.

173 Differential diagnosis - Differing from Hispanomys daamsi, H. thaleri, $H$.

174 freudenthali and $H$. adroveri, in being smaller; differing from $H$. bijugatus, $H$. thaleri,

$175 H$. moralesi, $H$. peralensis, $H$. baixasi, $H$. freudenthali, and $H$. adroveri in having strong

176 labial cingula surrounding the valleys on the M1; differing from $H$. bijugatus, $H$.

177 aragonensis, $H$. thaleri, $H$. moralesi, $H$. peralensis, $H$. baixasi, $H$. freudenthali, and $H$.

178 adroveri in having strong labial cingula surrounding the valleys on the M2; differing

179 from $H$. mediterraneus, $H$. moralesi, $H$. peralensis, $H$. freudenthali, and $H$. adroveri in

180 having four-rooted M1; differing from $H$. dispectus, $H$. thaleri, $H$. mediterraneus, $H$.

181 moralesi, $H$. peralensis, $H$. freudenthali, and $H$. adroveri in having incomplete

182 ectolophs on the M1 and M2; differing from H. castelnovi, H. bijugatus, $H$. daamsi, $H$.

183 aguirrei, $H$. nombrevillae, $H$. lavocati, $H$. mediterraneus, $H$. moralesi, $H$. peralensis, $H$.

184 freudenthali, and $H$. adroveri in having an enamel-coated valley on many M1-M2;

185 differing from $H$. castelnovi, $H$. bijugatus, $H$. nombrevillae, $H$. mediterraneus, $H$.

186 moralesi, $H$. peralensis, $H$. freudenthali, and $H$. adroveri in having usually a mesoloph

187 on the M1; differing from $H$. castelnovi, $H$. dispectus, $H$. nombrevillae, $H$. thaleri, $H$.

188 mediterraneus, $H$. moralesi, $H$. peralensis, $H$. freudenthali, and $H$. adroveri in having 
the M3 less reduced; differing from $H$. moralesi, $H$. peralensis, $H$. freudenthali, and $H$.

190 adroveri in having labial anterolophid in all $\mathrm{m} 1$; differing from $H$. castelnovi, $H$.

191 daamsi, H. dispectus, H. thaleri, H. baixasi, H. aragonensis, H. moralesi, H. peralensis,

192 H. freudenthali, and H. adroveri in having a double metalophid on some m1; differing

193 from $H$. thaleri, H. nombrevillae, and H. aguirrei in having three-rooted $\mathrm{m} 2$; differing

194 from $H$. nombrevillae, $H$. aguirrei, H. moralesi, $H$. peralensis, $H$. freudenthali, and $H$.

195 adroveri in having the $\mathrm{m} 3$ less reduced.

196

197 3. 1 Description

198 i: The incisor enamel bears in its labial side two feeble longitudinal ridges.

$199 \mathrm{~m} 1$ : The outline of these teeth in occlusal view is sub-rectangular, longer than wide,

200 with its anterior part somewhat rounded and narrower than the posterior one. The

201 lingual anterolophid is usually lacking, but in few specimens (e.g. FSL 67005) it is

202 present, but weak. The labial anterolophid is long and prominent and can even reach the

203 anterior side of the protoconid, closing thereby the protosinusid. The $\mathrm{m} 1$ have a double

204 metalophulid (e.g. FSL 67003, Fig. 1-d) or a short mesolophid (FSL 67005, FSL 67001,

205 Figs. 1-a, 1-c). Some teeth clearly show both structures (e.g. FSL 67002, Fig. 1-b). Even

206 when the mesolophid is lacking, there is a slight inflation at the end of the posterior arm

207 of the protoconid. The hypolophulid is transverse. A few teeth have an ectomesolophid

208 (FSL 67000, Fig. 2). All the specimens have a labial cingulum surrounding the sinusid.

209 This cingulum is constituted by the junction of two ridges: the first emerging from the

210 posterior wall of the protoconid and the second from the anterior wall of the hypoconid.

211 It can bear an ectostylid. Some $\mathrm{m} 1$ also show a thin, low ridge surrounding the lingual

212 valley. The sinusid is antero-lingually directed. The posterolophid is short and 
213 constricted behind the hypoconid; it does not reach the posterior wall of the entoconid.

214 These teeth are two-rooted.

$215 \mathrm{~m} 2$ : These teeth are rectangular in shape, though they are anteriorly and posteriorly

216 slightly rounded. They show a prominent labial anterolophid that reaches the

217 anterolabial side of the protoconid, closing thereby the protosinusid. The metalophulid

218 is anterolabially directed and the hypolophulid is transverse. The mesolophid is usually

219 short and ends free. The $\mathrm{m} 2$ have rarely lingual cingula surrounding the valleys (e.g.

220 FSL 67006), but all of them have strong labial cingula closing the sinusid. These

221 cingula are constituted by two ridges; the first (which is stronger) emerging from the

222 posterior wall of the protoconid and the second from the anterior wall of the hypoconid.

223 The sinusid is transverse. The posterolophid is short and constricted behind the

224 hypoconid; it does not reach the posterior side of the entoconid. The posterior root splits

225 into two and, therefore, these teeth are three-rooted. The posterolabial root is stronger

226 than the posterolingual one.

$227 \mathrm{~m} 3$ : The occlusal outline of these teeth is rounded, longer than wide, with its

228 posterior part narrower than the anterior one. They show a long and strong labial

229 anterolophid that connects with the anterior wall of the protoconid, closing the

230 protosinusid. The lingual anterolophid is absent. Most of the specimens have a short

231 mesolophid (FSL 67002, FSL 67003, Figs. 1-b, 1-d). However, 4 out of 27 have it long

232 (e.g. FSL 67001, FSL 67005, FSL 67054, FSL 67057 Figs 1-a, 1-c). From these, three

233 specimens (FSL 67001, FSL 67005, FSL 67054) have the mesolophid connected to the

234 anterior side of the entoconid. The posterosinusid and mesosinusid are open; there are

235 no lingual cingula surrounding the valleys. The sinusid is slightly posteriorly directed; it

236 may be partially closed by two ridges: the strongest emerges from the posterior wall of 
237 the protoconid, whereas the other one comes out from the anterior wall of the

238 hypoconid. The posterolophid is short and does not join the posterior wall of the

239 entoconid. These teeth are three-rooted.

$240 \quad$ M1: These teeth show a pronounced groove between the two lobes of the anterocone.

241 Most of the specimens show either a strong cusp (even two) in the prelobe or a low

242 anterior ridge in front of the anterocone (e.g. Fig. 3-h). The anterolophule connects the

243 lingual lobe of the anterocone with the protocone. The protosinus is closed by a large

244 protostyle (Figs. 3-d, 3-h, 3-i, 3-1) or by a low and strong ridge (Fig. 3-a). The

245 protolophule is anterolabially directed. The anterior ectoloph is well developed and ends

246 free most of the time. It can be parallel to the longitudinal axis of the tooth or postero-

247 lingually directed. The fordward paracone spur is usually absent. The long and strong

248 backward paracone spur connects to the posterior ectoloph closing the mesosinus, but it

249 ends free in some specimens. The backward paracone spur emerges at about the

250 midpoint between the labial side of the tooth and the entoloph. Most of the specimens

251 have a short or medium mesoloph. In some of them, the mesoloph connects labially to a

252 lingual spur of the backward paracone spur that points towards the mesoloph (Fig. 3-1),

253 isolating a circular valley (called enamel-coated valley), which dissapears through wear.

254 Otherwise these structures are too short to be connected (Fig. 3-h, 3-i, 3-k). The M1 of

255 Hispanomys decedens have strong, low cingula surronding the labial valleys; some of

256 which bears a mesostyle. The anteriorly directed sinus is usually partially closed by a

257 strong entostyle or by a ridge, which emerges from the hypocone towards the

258 posteriolabial side of the protocone. Some specimens (e.g. FSL 67015, Figs. 3-i, 3-j)

259 and FSL 67017 (Fig. 3-h) show a vertical ridge emerging from the posterior wall of the

260 protocone towards the lingual side of the tooth (a sort of vestigial entomesoloph). In the 
less worn specimens, it is possible to observe that both lingual and labial posterolophs are short, but distinct. These teeth are four-rooted.

M2: The outline of these teeth in occlusal view is sub-rectangular, longer than wide, with its posterior part somewhat rounded and narrower than the anterior one. They have quite developed lingual anteroloph and a small, but distinct, protosinus in the anterior margin of the teeth. The labial anteroloph is well developed. The anterosinus is usually open due to the absence of anterior ectoloph, forward paracone spur or both (e.g. Figs. 3-e, 3-g, 3-m). However, some of the M2 have the anterior ectoloph connected to the forward paracone spur, closing the anterosinus (e.g. Figs. 3-d, 3-f). The backward paracone spur is long and strong and usually reachs the posterior ectoloph (a small anterior ridge of the metacone) and, in so doing, entirely closes the mesosinus. Nevertheless, some specimens lack the posterior ectoloph and, therefore, have a backward paracone spur that ends free (e.g. Fig. 3-m) or the two crests are not connected (e.g. Fig. 3-f). All teeth have the mesosinus much larger than the anterosinus and they have a cingulum surronding the main labial valley. A lesser number of M2 than M1 shows the mesoloph. When present, it is short or of medium length; in some specimens it reaches the backward paracone spur forming an enamel-coated valley (e.g. Fig. 3-m). The enamel-coated valley is formed by the connection of the mesoloph with

279 a lingual spur emerging from the backward paracone spur. In some specimens, the

280 mesoloph and the backward paracone spur are too short and, therefore, they are

281 disconnected (Fig. 3-e). The presence of a mesoloph on the M2 is related to the 282 presence of a mesoloph on the M1. Every M2 that lacks the mesoloph shows a slight

283 inflation at the beginning of the anterior arm of the hypocone (Figs. 3-d, 3-f). The 284 backward paracone spur is long and usually posterolabially oriented; in some specimens 
285 (Fig. 3-d) it emerges practically at the midpoint of the protolophule. The protolophule is 286 slightly oblique and anterolabially directed. The sinus is nearly closed by a low ridge

287 that emerges from the anterior side of the hypocone towards the posterior side of the 288 protocone. These teeth show short labial and lingual posterolophs. They have four roots.

289 M3: The outline of these teeth in occlusal view is rounded, longer than wide, with 290 the posterior part narrower than the anterior one. The labial anteroloph is long; the 291 lingual one is much less developed, but distinct (except in worn specimens). The 292 anterior ectoloph and the fordward paracone spur are lacking and the anterosinus is 293 open. A true mesoloph is lacking in all M3 of Hispanomys decedens, but some show a

294 small inflation corresponding to this ridge (Fig. 4-d). The teeth have a short, but 295 distinct, posteroloph and a posterosinus. The well-developed backward paracone spur 296 ends usually free due to the absence of the posterior ectoloph. The posterolabial side of

297 the protocone generally has a strong ledge, which is directed towards the hypocone.

298 This ledge closes the sinus partially. The sinus is directed backwards. These teeth are 299 not reduced; actually, the value of the ratio mean LM1/mean LM3 of the teeth is very 300 low (=1.736), one of the lowest ones obtained for any Hispanomys species known to 301 date (López Antoñanzas and Mein 2009). These molars are three-rooted.

\section{Discussion}

In 1966, Freudenthal based on the cricetodontine material from the localities of

306 Nombrevilla and Pedregueras 2C (Zaragoza, Spain) he studied to coin two new

307 subspecies of Cricetodon decedens in addition to $C$. decedens decedens: $C$. decedens

308 aragonensis and C. decedens nombrevillae. Later on, Mein and Freudenthal (1971: 19) 
309 introduced the new subgenus Hispanomys and raised these subspecies to the species

310 level.

311 Freudenthal's (1966) decision of regarding the two taxa as subspecies of $C$. decedens

312 was the result of the lack of information available at that time about the "typical"

313 decedens from La Grive-Saint Alban. Actually, Freudenthal (1966) did not discard the

314 possibility that, once the material from La Grive-Saint Alban is studied in detail, one of

315 the two subspecies he named could turn out to be a synonym of decedens. However, he

316 thought more likely that the Spanish subspecies were different from the French one, a

317 conclusion that the present work supports.

318 The detailed study of Hispanomys decedens from La Grive-Saint Alban shows that

319 this taxon is, in fact, very different from H. nombrevillae and, even though it seems

320 closely related to $H$. aragonensis from Pedregueras, both species can be easily

321 differenciated (see below).

322 The main characters usually used to establish the evolutionary stage of the

323 Hispanomys species are: 1) the different development of the ectolophs; 2) the degree of

324 reduction of the mesolophs and mesolophids; 3) the presence or loss of labial

325 anterolophids; 4) the presence or loss of cingular structures; 5) the acquisition or not of

326 extra roots; 6) the degree of reduction of the third molars; and 7) the degree of

327 hypsodonty (van de Weerd 1976; Agustí 1981, 1982, López-Antoñanzas and Mein

328 2009; López-Antoñanzas et al. 2010). The most archaic morphologies of Hispanomys

329 would be characterized by having lower molars with well-developed labial

330 anterolophids, lingual anterolophids, lingual cingula surrounding the valleys, two-rooted

$331 \mathrm{~m} 2$, and unreduced $\mathrm{m} 3$. Besides, the most primitive upper molars would be

332 characterized by having mesolophs, labial cingula surrrounding the valleys, quite 
333 incomplete ectolophs, four-rooted M1, and unreduced M3 (van de Weerd, 1976; Agustí

334 1981, 1982; López-Antoñanzas and Mein 2009; López-Antoñanzas et al. 2010)

$335 H$. decedens and H. aragonensis share some primitive character states as the

336 presence of a mesoloph forming an enamel-coated valley on the M1 and M2 and the

337 presence of labial cingula surrounding the M1 as well as some derived ones like the

338 absence of a mesoloph on the M3 and the splited posterior root on the $\mathrm{m} 2$. However,

339 there are also differences between these species that makes $H$. decedens a reasonable

340 forerunner of $H$. aragonensis. In the latter species, there is a trend towards the decrease

341 in the proportion of M1 and M2 with the mesoloph and in that of M1 with either

342 anterior cingulum or anterostyle in the prelobe. Besides, another progressive character

343 distinguishing $H$. aragonensis from $H$. decedens is the lack of the labial cingulum

344 surrounding the valley on M2. Therefore, $H$. aragonensis shows a trend to lose archaic

345 characters so characteristic of $H$. decedens.

346 Moreover, if we compare the dental evolutionary stage of Hispanomys decedens and

347 the Upper Aragonian and Lower Vallesian species of Hispanomys, it appears that the

348 former shows a quite primitive morphology.

349 Thus, Hispanomys decedens is more primitive than $H$. castelnovi, H. bijugatus, $H$.

350 aguirrei, H. daamsi, H. lavocati, and H. nombrevillae in having well-developed

351 mesolophs on M1 and M2, which tend to form an enamel-coated valley. Well-

352 developed mesolophs are also present, but in much lesser proportion, in $H$. thaleri (a

353 few upper molars) and in H. aragonensis. Besides, H. decedens seems more primitive

354 than H. castelnovi, H. bijugatus, and H. thaleri in having strong cingula surrounding the

355 labial valleys of the first and second upper molars. Regarding the reduction of the third

356 molars, this taxon is also quite primitive: $H$. decedens appears more primitive than $H$. 
357

358

359

360

361

362

363

364

365

366

367

368

369

370

371

372

373

374

375

376

377

378

379

380

castelnovi, $H$. dispectus, $H$. nombrevillae, and $H$. thaleri in having the M3 much less reduced (López-Antoñanzas et al., 2010, table 2). This character is shared with the other species of Hispanomys from La Grive-Saint Alban: H. bijugatus.

\section{Conclusion}

So far, Hispanomys includes 17 species with a stratigraphical distribution that encompasses nearly 10 m.y. Among them, ten taxa are known from the Upper Aragonian and Lower Vallesian: Hispanomys castelnovi, H. decedens, H. bijugatus, $H$. aguirrei, $H$. daamsi, $H$. dispectus, $H$. thaleri, $H$. lavocati, $H$. nombrevillae, and $H$. aragonensis.

Hispanomys decedens from La Grive-Saint Alban has most of the typically primitive dental characters of the Aragonian species of Hispanomys, such as the not reduced M3, the labial cingula surrounding the first and second molar valleys, and the presence of mesolophs on the upper molars forming an enamel-coated valley. This suggests that $H$. decedens is a quite primitive species with respect to the coeval congeneric taxa. In addition, the detailed study of $H$. decedens from La Grive-Saint Alban shows that this taxon could be an ancestor of $H$. aragonensis.

Acknowledgements J. van Dam and W. Wessels (Rijksuniversiteit Utrecht, Utrecht) kindly lent material of Hispanomys housed in their institution. L. Celià Gelabert and J. Galindo Torres (Instituto Catalán de Paleontología, Sabadell) allowed the examination of material under their care. Thanks to J. Prieto (Ludwig-Maximilians-Universität, Munich) and an anonymous reviewer for having improved this work through critical 
reading. Discussion with P. Peláez-Campomanes (Museo Nacional de Ciencias

Naturales-CSIC, Madrid) was much appreciated. This study has been partly founded by research project CGL2008-05813-CO2-01 (MICINN, Spanish Government) conducted

by J. Morales. R.L.A. is currently supported by a Ramón y Cajal research contract.

\section{References}

Agustí, J. (1981). Roedores miomorfos del Neógeno de Cataluña. Ph.D. dissertation. Barcelona: Universidad de Barcelona.

Agustí, J. (1982). Tendencias evolutivas de la línea Cricetodon-Ruscinomys (Rodentia, Mammalia) en la Península Ibérica. Acta Geologica Hispánica, 17, 103-111.

Alba, D. M., Moyà-Solà, S., Casanovas-Vilar, I., Galindo, J., Robles, J. M., Rotgers, C., Furió, M., Angelone, C., Köhler, M., Garcés, M., Cabrera, L., Almécija, S., \& Obradó, P. (2006). Los vertebrados fósiles del Abocador de Can Mata (els Hostalets de Pierola, l'Anoia, Cataluña). Estudios Geológicos, 62, 295-312.

Casanovas Vilar, I. (2007). The rodent assemblages from the Late Aragonian and the Vallesian (Middle to Late Miocene) of the Vallès-Penedès basin (Catalonia, Spain). Ph.D. dissertation. Barcelona: Universidad de Barcelona.

Depéret, C. (1887a). Recherches sur la succession des faunes de Vertébrés miocènes de la Vallée du Rhône. Archives du Muséum d'Histoire naturelle de Lyon, 4, 45-313.

Depéret, C. (1887b). Sur la faune de Vertébrés miocènes de la Grive-Saint-Alban (Isère). Comptes Rendus des Séances de l'Académie des Sciences, 104, 379-381.

403 Ennouchi, E. (1930). Contribution à l'étude de la faune du tortonien de La Grive St404 Alban (Isère). Paris: Les Presses modernes, 135 pp. 
Freudenthal, M. (1966). On the mammalian fauna of the Hipparion beds in the Nederlandse Akademie Van Wetenschappen B, 69, 296-317.

409 Freudenthal, M., Hugueney, M., \& Moissenet, E. (1994). The genus Pseudocricetodon 410 (Cricetidae, Mammalia) in the Upper Oligocene of the province of Teruel (Spain). Scripta Geologica, 104, 57-114.

412 López-Antoñanzas, R., \& Mein, P. (2009). First detailed description of Hispanomys bijugatus Mein et Freudenthal, 1971 (Rodentia) from La Grive-Saint Alban (France): biostratigraphical implications. Geobios, 42, 783-796.

López-Antoñanzas, R., Pelaez-Campomanes, P., Álvarez-Sierra, M. A., \& GarcíaParedes, I. (2010). New species of Hispanomys (Rodentia, Cricetodontinae) from the Upper Miocene of Batallones (Madrid, Spain). Zoological Journal of the Linnean Society, 160, 725-747.

Mein, P., \& Freudenthal, M. (1971). Une nouvelle classification des Cricetidae (Mammalia, Rodentia) du Tertiaire de 1'Europe. Scripta Geologica, 2, 1-37.

Mein, P., \& Ginsburg, L. (2002). Sur l'âge relatif des différents dépôts karstiques

424 Schaub, S. (1925). Die Hamsterartigen Nagetiere des Tertiärs und ihre lebenden Verwandten. Abhandlungen der Schweizerischen paläontologische Gesellschaft, $45,1-114$. Helvetiae, 37, 453-457. 
429 Schaub, S. (1947). Los Cricetodóntidos del Vallés-Panadés. Estudios Geologicos, 6,

430 $55-67$.

431 Van de Weerd, A. (1976). Rodents fauna of the Mio-Pliocene continental sediments of the Teruel-Alfambra region, Spain. Utrecht micropaleontological Bulletins,

433 Special publication, 2, 1-185.

434 
436 Table 1. Length and width measurements $(\mathrm{mm})$ of the lower and upper molars of

437 Hispanomys decedens from La Grive-Saint Alban, Isère, France. Except for one m1

438 (from Carrière M) and two M3 (from Carrière L, fissure L7), all the specimens are

439 supposed to come from fissure L5'.

440

\begin{tabular}{|c|c|c|c|c|c|c|c|c|c|c|}
\hline \multirow[b]{2}{*}{ Locality } & \multicolumn{6}{|c|}{ LENGTH } & \multicolumn{4}{|c|}{ WIDTH } \\
\hline & $\begin{array}{c}\text { Tooth } \\
\text { type }\end{array}$ & $\min$ & mean & $\max$ & sd & $\mathbf{N}$ & $\min$ & mean & $\max$ & sd \\
\hline \multirow{6}{*}{ La Grive-St Alban } & $\mathrm{m} 1$ & 2.44 & 2.60 & 2.80 & 0.09 & 29 & 1.60 & 1.69 & 1.78 & 0.05 \\
\hline & M1 & 2.74 & 3.16 & 3.59 & 0.18 & 62 & 1.76 & 2.05 & 2.31 & 0.10 \\
\hline & $\mathrm{m} 2$ & 2.27 & 2.48 & 2.69 & 0.09 & 34 & 1.80 & 1.94 & 2.08 & 0.08 \\
\hline & M2 & 2.14 & 2.43 & 2.69 & 0.15 & 54 & 1.72 & 1.92 & 2.23 & 0.12 \\
\hline & $\mathrm{m} 3$ & 1.92 & 2.23 & 2.42 & 0.15 & 25 & 1.63 & 1.79 & 1.93 & 0.08 \\
\hline & M3 & 1.64 & 1.82 & 2.09 & 0.12 & 26 & 1.50 & 1.68 & 1.90 & 0.09 \\
\hline
\end{tabular}

441

442 
Fig. 1. Lower molars of Hispanomys decedens from La Grive Saint-Alban (fissure

L5'). a. Left mandible with m1-m3 (FSL 67005). b. Left mandible with m1-m3 (FSL

67002). c. Right mandible with m1-m3 (FSL 67001). d. Right mandible with m1-m3

(FSL 67003). e. Left mandibular fragment with m1-m2 (FSL 67004). f. Close-up of the metalophulid II of specimen FSL 67004. Scale bar represents 2mm, except for f $(200 \mu \mathrm{m})$.

452

Fig. 2. Hispanomys decedens from La Grive Saint-Alban (fissure L5'). a. Left mandible with m1-m3 (FSL 67000). Scale bar represents 2mm. b. Close-up of the ectomesolophid of the $\mathrm{m} 1$ of specimen FSL 67000. Scale bar represents $500 \mu \mathrm{m}$.

456

Fig. 3. Upper molars of Hispanomys decedens from La Grive Saint-Alban (fissure L5'). a. Right maxilla with M1-M3 (FSL 67007). b. Close-up of the mesoloph of the M1 of specimen FSL 67007. c. Close-up of the mesoloph of the M2 of specimen FSL 67007. d. Left maxilla with M1-M3 (FSL 67009). e. Left M2 (FSL 67019). f. Left maxilla with M1-M3 (FSL 67011). 7. Left M2 (FSL 67020). g. Left M1 (FSL 67012). h. Left M1 (FSL 67015). i. Close-up of the entomesoloph of specimen FSL 67015. j.

463 Close-up of the mesoloph of specimen FSL 67015. k. Left M1 (FSL 67017). 1. Left 464 maxilla with M1-M2 (FSL 67008). Scale bar represents 2mm, except for b-c (300 $\mu \mathrm{m})$ 465 and j-k $(500 \mu \mathrm{m})$. 

decedens and H. bijugatus from La Grive-Saint Alban (France).

469 


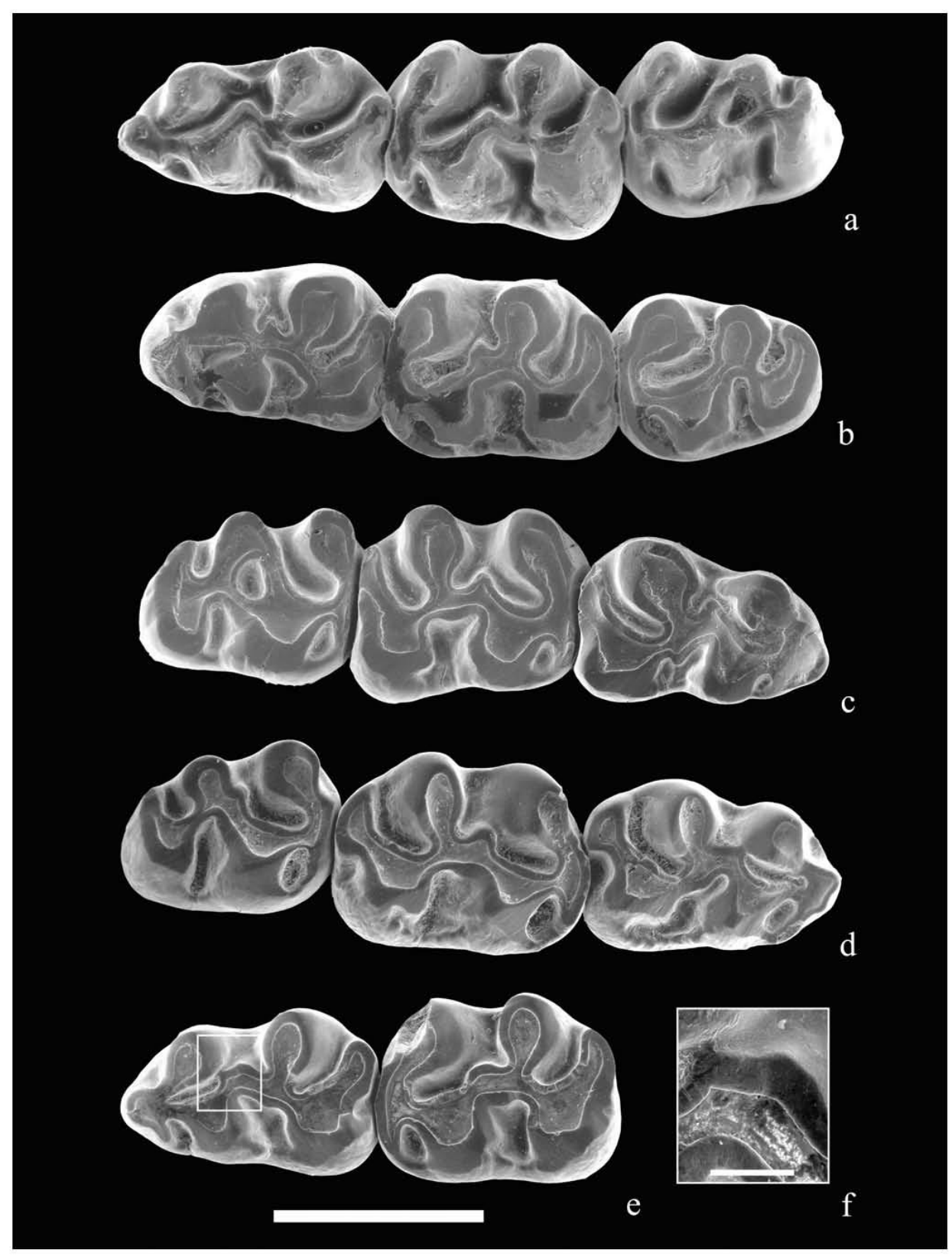

470 




471

472 Figure 1

473 


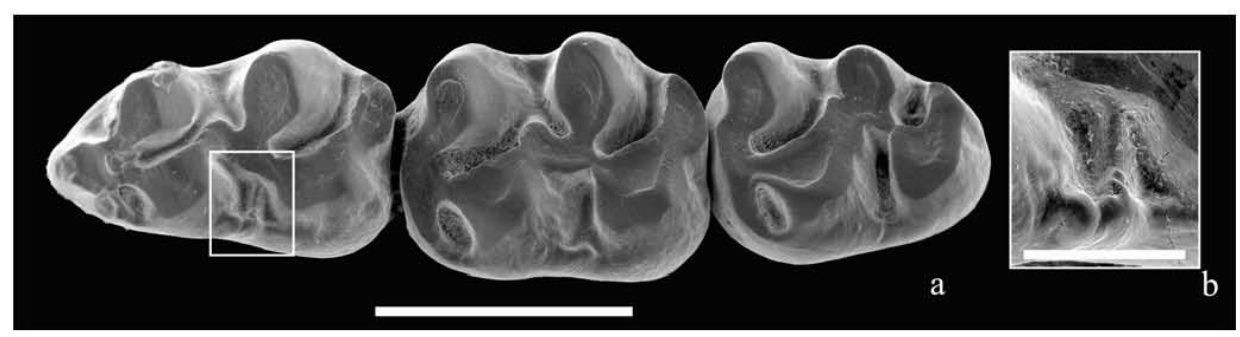

474

475 Figure 2

476 


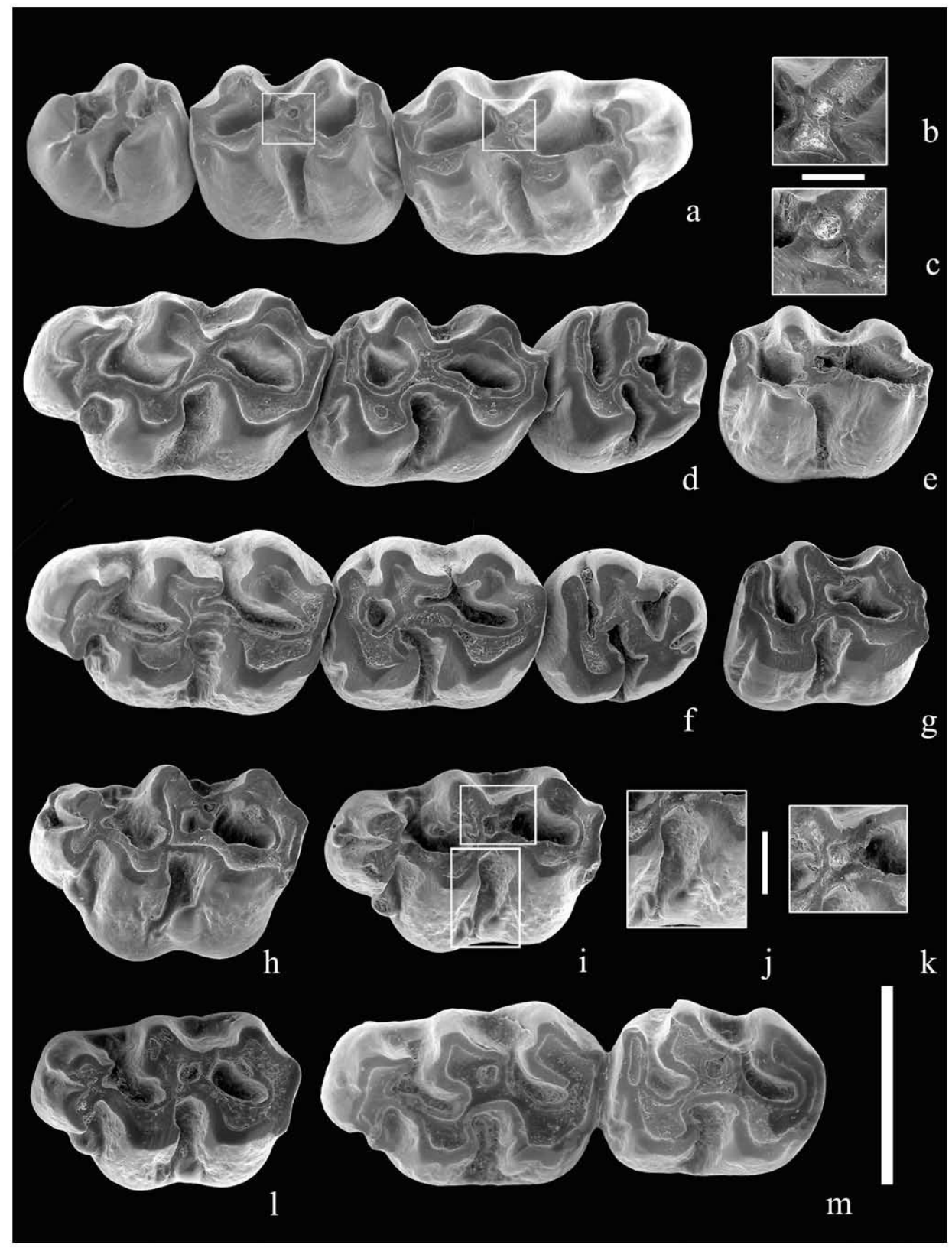

477

$478 \quad$ Figure 3

479 

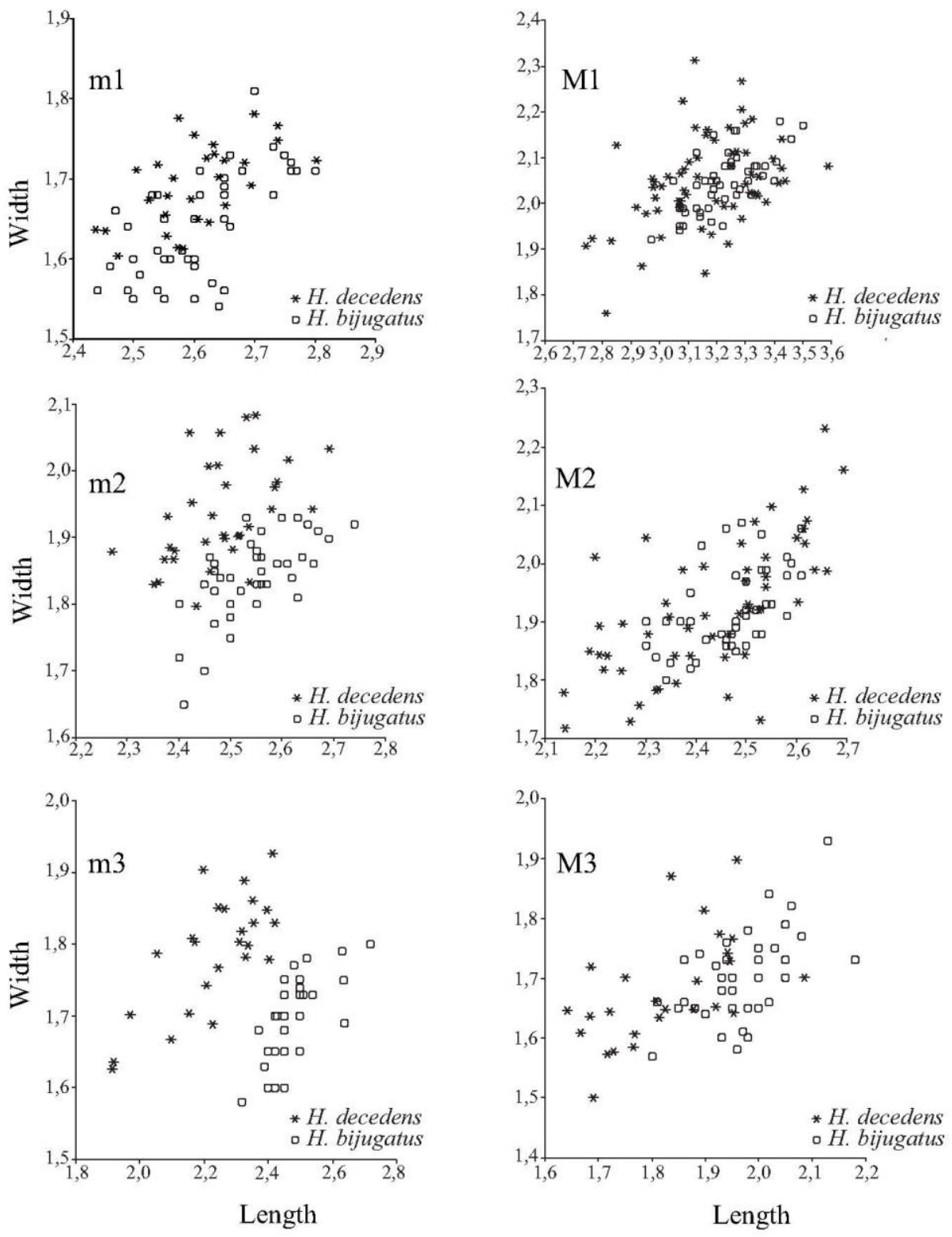

Figure 4 